\title{
Community composition and activity state of estuarine bacterioplankton assessed using differential staining and metagenomic analysis of 16S rDNA and rRNA
}

\author{
Rima B. Franklin ${ }^{1}$, Catherine Luria ${ }^{1,4}$, Luiz Shozo Ozaki ${ }^{2}$, Paul A. Bukaveckas ${ }^{1,3, *}$ \\ ${ }^{1}$ Department of Biology, ${ }^{2}$ Center for the Study of Biological Complexity, Department of Microbiology and Immunology, \\ and ${ }^{3}$ Center for Environmental Studies, Virginia Commonwealth University, Richmond, Virginia 23284, USA
}

${ }^{4}$ Present address: Department of Ecology and Evolutionary Biology, Brown University, Providence, Rhode Island 02906, USA

\begin{abstract}
To better understand how resource availability controls estuarine microbial communities, we compared community composition at 2 sites in the tidal freshwater James River (Virginia, USA) which differed in nutrient concentrations and autochthonous production. In addition, we conducted laboratory microcosm experiments, wherein bacteria from the 2 sites received nutrient, light, and organic carbon amendments. Traditional, microscopy-based methods of staining and enumeration were used to determine the abundance of total, live, and active cells. DNA fingerprinting (terminal restriction fragment length polymorphism, TRFLP) and dual 16S rDNArRNA pyrosequencing were used to assess community composition and taxon-specific activity (from rRNA:rDNA). Enumeration revealed that total, live, and active (CTC+) bacteria were more abundant at the site where autochthonous production was higher, while DNA fingerprinting (TRFLP) and 16S rDNA pyrosequencing indicated high similarity in community composition at the 2 sites. In contrast, pyrosequencing results from rRNA revealed greater variation and suggest that the metabolically active fraction of the community differed between sites. Differences in rDNAand rRNA-based libraries were also apparent in microcosm experiments, where resource amendments resulted in shifts in both the active and overall communities. In both environmental and microcosm samples, dual rDNA-rRNA pyrosequencing yielded higher estimates of the proportion of active cells $(32 \pm 3 \%)$ compared to differential staining and microscopy $(13 \pm 1 \%)$. Though characterization of active taxa was sensitive to the presumed activity threshold (rRNA:rDNA), our findings suggest that variable resource conditions can give rise to unique assemblages of active taxa despite similarities in overall community composition.
\end{abstract}

KEY WORDS: Activity state - Bacteria - Community composition - Estuary - Pyrosequencing • Chesapeake Bay

Resale or republication not permitted without written consent of the publisher

\section{INTRODUCTION}

Bacterioplankton play a fundamental role in aquatic ecosystems through their regulation of nutrient and organic matter cycles (Azam et al. 1983, Sherr \& Sherr 1988, Kirchman 1994). Studies in diverse aquatic environments have shown that bac- terial abundance and community composition covary with numerous factors including organic matter sources and composition (Cherrier et al. 1996, Eiler et al. 2003), nutrient availability (Stepanauskas et al. 1999, Frette et al. 2009), water temperature (Shiah \& Ducklow 1994, 1995, McManus et al. 2004), predation (Jürgens \& Güde 1994, Gasol et al. 2002), and 
viral lysis (Thingstad \& Lignell 1997). Determining the relative importance of these factors is challenging, particularly in estuaries, which experience large and frequent changes in environmental conditions. In these systems, tidal-driven exchanges with the marine environment and episodic riverine inputs alter salinity, inorganic nutrients, and the quality and quantity of organic matter along the longitudinal axis of the estuary. Mechanisms of bacterial community response to these factors are poorly understood, but can include shifts in bacterial abundance, community composition, and activity state.

The analysis of whole-community DNA extracts from environmental samples has been used to characterize variation in estuarine bacterioplankton in response to changes in resources and physicalchemical conditions (Troussellier et al. 2002, Crump et al. 2004, Henriques et al. 2004, Kirchman et al. 2005). However, DNA is present in dormant and even dead cells, which account for a large proportion of bacterial communities (Cole 1999, Sherr et al. 1999, Bouvier \& del Giorgio 2002, del Giorgio \& Gasol 2008). For example, staining with 5-cyano2,3-ditolyl tetrazolium chloride (CTC) suggests that the proportion of cells that are respiring is typically 1 to $10 \%$ in diverse aquatic systems (del Giorgio \& Scarborough 1995, Choi et al. 1996, Karner \& Fuhrman 1997). The essential functions of bacterial communities are apparently carried out by the small proportion of the community that is metabolically active (Bakken \& Olsen 1987, Epstein 2009). Taxonomic composition of the active and inactive components of the community is unknown, though shifts in activity state have frequently been invoked to explain functional changes where overall community composition changes little (Freitag et al. 2006, Crump et al. 2007, Kan et al. 2007).

While DNA-based methods cannot distinguish active from inactive taxa, simultaneous characterization of rRNA may provide a means for identifying the metabolically active fraction of bacterial communities. As bacterial growth rates correlate with cellular rRNA content (Rosset et al. 1966, Wagner 1994, Manefield et al. 2002), the presence of bacterial 16S rRNA indicates taxa that are metabolically active. Analysis of rRNA has been utilized in 'community fingerprinting' studies, whereby similarity is assessed in the absence of information on specific taxa (Koizumi et al. 2003, Pennanen et al. 2004, RodríguezBlanco et al. 2009). Jones \& Lennon (2010) were the first to use high-throughput sequencing of both $16 \mathrm{~S}$ rDNA and rRNA as a means of identifying metabolically active taxa. They found that $16 \mathrm{~S}$ rDNA and
rRNA libraries of samples collected from 2 lakes differed in their dominance hierarchies, indicating variable activity states of specific taxa. This approach has the potential to provide new insight into mechanisms of bacterial community response to changing resource conditions by characterizing the taxa that comprise the active subset of the community.

In this study, we describe bacterial responses to varying resource and environmental conditions based on changes in abundance, community composition, and activity state. We exploited a longitudinal gradient in autochthonous production and inorganic nutrient concentrations in the tidal freshwater segment of the James River (Virginia) to compare community characteristics at 2 sites differing in organic matter and nutrient conditions. We also conducted laboratory experiments to assess the effects of resource limitation on bacterial communities collected from these sites. Terminal restriction fragment length polymorphism (TRFLP) DNA fingerprinting was used to examine bacterioplankton community composition, and dual 16S rDNA-rRNA pyrosequencing was employed to classify metabolically active taxa.

\section{MATERIALS AND METHODS}

\section{Field study}

Environmental sampling entailed monthly collections during peak primary production (May to September 2009) from Chesapeake Bay Program Monitoring stations located at river mile 75 (GPS: 37.312649, -77.232826) and 99 (GPS: 37.400982, -77.387001) within the tidal freshwater James River (values denote distance inland from the confluence with Chesapeake Bay; hereafter, JMS75 and JMS99). The sites were selected based on prior work showing large differences in chlorophyll a (chl a), net primary production (NPP) and bacterial abundance (BA) (Bukaveckas et al. 2011). JMS75 is located in a region where the estuary becomes wider and shallower resulting in more favorable light conditions with high chl $a$ and NPP, as well as declining concentrations of dissolved inorganic nutrients. JMS99 is located in a narrower, deeper segment of the estuary where unfavorable light conditions result in low chl $a$ and NPP; nutrient concentrations are higher at this site. Both sites are vertically well-mixed and salinity is always less than $0.5 \mathrm{ppt}$ (average of monthly samples, 2005 to 2010). Samples for the present study were collected near 
the surface $(<1 \mathrm{~m})$ and transported $(<1 \mathrm{~h})$ to the laboratory in 21 opaque Nalgene bottles at ambient temperatures. Temperature, conductivity, and turbidity were measured in the field with a Hach Hydromet water quality sonde.

\section{Microcosm experiments}

Coincident with each field sampling, water samples (20 1 carboys) were collected from the 2 sites for laboratory microcosm experiments. Triplicate microcosms (sterile 21 Erlenmeyer flasks containing 11 water) were incubated for each of 5 treatment conditions: (1) 'Control' with ambient light and no amendments (to test for enclosure effects), (2) enhanced 'Light' (to stimulate phytoplankton production), (3) elevated 'Glucose' (to provide a labile organic matter source), (4) elevated 'Nutrients' (N and P), and (5) a fully 'Combined' treatment with enhanced light, glucose and nutrients (to test for colimitation). Ambient and enhanced light levels (100 and $400 \mu \mathrm{E} \mathrm{m} \mathrm{m}^{-2} \mathrm{~s}^{-1}$, respectively; $8 \mathrm{~h}$ photoperiod) were determined according to typical daily incident solar radiation, water depth, and light attenuation. Glucose amendments (1 $\mathrm{mg} \mathrm{l}^{-1}$ glucose-C) were equivalent to $20 \%$ of ambient dissolved organic carbon (DOC) concentrations (cf. Hoikkala et al. 2009) in the James River Estuary. Nutrient amendments included both phosphorus (as $\mathrm{Na}_{2} \mathrm{HPO}_{4}$ ) and nitrogen (as $\mathrm{NH}_{4} \mathrm{Cl}$ and $\mathrm{NaNO}_{3}$ ) to twice that of typical in situ concentrations (for JMS99: $33 \mu \mathrm{g} \mathrm{l}^{-1} \mathrm{PO}_{4}{ }^{3-}-\mathrm{P}$,

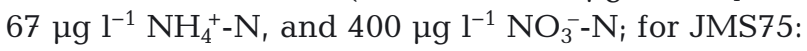
$15 \mathrm{\mu g} \mathrm{l}^{-1} \mathrm{PO}_{4}{ }^{3-}-\mathrm{P}, 60 \mu \mathrm{g} \mathrm{l}^{-1} \mathrm{NH}_{4}^{+}-\mathrm{N}$, and $50 \mu \mathrm{g} \mathrm{l}^{-1}$ $\left.\mathrm{NO}_{3}^{-}-\mathrm{N}\right)$. Microcosms were incubated at ambient river temperatures which ranged from $19^{\circ} \mathrm{C}$ (May) to $29^{\circ} \mathrm{C}$ (August). Chemistry and microbiological samples were obtained at the conclusion of the $48 \mathrm{~h}$ experiment. Results from individual monthly experiments are described elsewhere (Luria 2010); herein, we focus solely on the September experiment for which dual RNA and DNA pyrosequencing data are available.

\section{Environmental parameters}

Field and microcosm samples were analyzed for total nitrogen $(\mathrm{TN})$, ammonium $\left(\mathrm{NH}_{4}{ }^{+}-\mathrm{N}\right)$, nitrate $\left(\mathrm{NO}_{3}{ }^{-} \mathrm{N}\right)$, total phosphorus (TP), soluble reactive phosphorus (SRP; $\left.\mathrm{PO}_{4}{ }^{3-}-\mathrm{P}\right), \mathrm{DOC}$, chl $a$, and BA. DOC samples $(50 \mathrm{ml})$ were filtered through Whatman GF/A filters and acidified to a $\mathrm{pH}$ of 2 with con- centrated $\mathrm{HCl}$ for later analysis using a Shimadzu TOC analyzer. Samples for chl a $(100 \mathrm{ml})$ were filtered onto Whatman GF/A filters, extracted in aqueous $(90 \%)$ acetone at $4{ }^{\circ} \mathrm{C}$ for $24 \mathrm{~h}$ and analyzed on a Turner Designs fluorometer. Nutrient analyses were performed on a Skalar Sans Plus segmented flow analyzer. In addition, NPP and community respiration (CR) were determined by the dissolved oxygen method (Dawes 1988) using triplicate light and dark bottles (60 ml BOD) incubated at in situ light and temperature for $8 \mathrm{~h}$ (NPP) and $24 \mathrm{~h}$ (CR).

\section{Bacterial abundance}

Triplicate $1 \mathrm{ml}$ samples were stained using the LIVE/DEAD ${ }^{\circledR}$ BacLight $^{\mathrm{TM}}$ Bacterial Viability and Counting Kit (Invitrogen), incubated for $10 \mathrm{~min}$ in the dark, and then filtered onto $0.2 \mu \mathrm{m}$ black-stained polycarbonate membrane filters (Millipore). Cells were counted manually using 1000× magnification (oil immersion) on an Olympus BX41 microscope; total BA was calculated as the sum of the counts of 'live' and 'dead' bacteria (i.e. intact cells plus those with compromised membranes). 'Active' cells were identified by staining with CTC (Sigma-Aldrich). Aliquots of sample $(2 \mathrm{ml})$ were incubated with $200 \mu \mathrm{l}$ CTC solution (15 mg ml-1) in the dark for $4 \mathrm{~h}$ on a rotary shaker set to $25 \mathrm{rpm}$, fixed by adding $53 \mu \mathrm{l}$ formalin, and counted within $24 \mathrm{~h}$ as described above.

\section{Isolation of nucleic acids}

For both DNA and RNA, triplicate samples were obtained by filtering $150 \mathrm{ml}$ of water through $0.22 \mu \mathrm{m}$ nitrocellulose filters (Millipore). Filters for RNA analysis were then saturated with $1 \mathrm{ml}$ RNAlater (Ambion) to prevent RNA degradation. All filters were stored at $-80^{\circ} \mathrm{C}$. DNA was extracted using a WaterMaster ${ }^{\mathrm{TM}}$ purification kit (Epicentre ${ }^{\circledR}$ Biotechnologies) according to the manufacturer's protocols; purifications were verified by gel electrophoresis and quantified using a Nanodrop Spectrophotometer. RNA was extracted using a RiboPure-Bacteria ${ }^{\mathrm{TM}}$ kit (Ambion) according to the manufacturer's protocol, including the optional DNase1 treatment, and then checked by gel electrophoresis. cDNA (hereafter referred to as rRNA for clarity) was synthesized from RNA using a High-Capacity cDNA Reverse Transcription Kit (Applied Biosystems) with 1 of the 4 forward primers described below in the 'Pyrosequencing' section. 


\section{TRFLP}

TRFLP of 16S rDNA was carried out using the following PCR conditions: an initial denaturation at $95^{\circ} \mathrm{C}$ for $3 \mathrm{~min}$, followed by 25 cycles of $94^{\circ} \mathrm{C}$ for $45 \mathrm{~s}$, $57^{\circ} \mathrm{C}$ for $1 \mathrm{~min}$, and $72^{\circ} \mathrm{C}$ for $2 \mathrm{~min}$, and then a final extension at $72^{\circ} \mathrm{C}$ for $7 \mathrm{~min}$. PCR reaction mixtures consisted of 1× PCR Buffer II (Applied Biosystems), $3 \mathrm{mM} \mathrm{MgCl}_{2}, 0.2 \mathrm{mM}$ (each) dNPT (GeneAmp), $0.2 \mu \mathrm{M}$ forward and reverse primers, $0.4 \mu \mathrm{g}$ bovine serum albumin (Roche), 2.5 units Taq polymerase (Amplitaq, Applied Biosystems), and $0.5 \mathrm{ng}$ template DNA in a final volume of $50 \mu \mathrm{l}$. The primers used were $27 \mathrm{~F}-\mathrm{FAM}$, with a fluorescently labeled 5 ' end, and 1492R (Polz \& Cavanaugh 1998). PCR products were purified using a Qiagen MinElute kit, and aliquots $(7 \mu \mathrm{l})$ were digested using 20 units MspI (New England Biolabs) in a final volume of $10 \mu \mathrm{l}$. Reaction mixtures were incubated for $6 \mathrm{~h}$ at $37^{\circ} \mathrm{C}$ followed by a $20 \mathrm{~min}$ incubation at $65^{\circ} \mathrm{C}$. Products were again purified with a Qiagen MinElute kit and analyzed by capillary electrophoresis on a MegaBACE 1000/4000 Series Sequencer (Amersham Biosciences) with an injection period of $100 \mathrm{~s}$ at $3000 \mathrm{~V}$ and a total run of $180 \mathrm{~min}$ at $10000 \mathrm{~V}$. TRFLP electropherograms were analyzed with Fragment Profiler Version 1.2 (Amersham Biosciences). Peaks were binned according to read number with a minimum of 3 peaks required for each bin and minimum bin size of 0.5 base pairs (bp). Shoulder peaks, peaks outside the 50 to 1000 bp range, and peaks less than 75 relative fluorescence units (rfu) in height were excluded. Peak data were converted into a binary matrix with 1 denoting presence and 0 denoting absence of a particular terminal restriction fragment.

\section{Pyrosequencing}

Pyrosequencing was performed for all environmental samples and for a subset of samples from the microcosm experiment (Control, Nutrient, and Combined treatments). The Nutrient and Combined treatments were selected based on the fact that they showed the greatest response to resource amendments, which manifested as an increase in net primary production and total bacterial abundance. In addition, we replicated sequence libraries from duplicate samples collected at JMS75 in May (rDNA only) and August (rDNA and rRNA). DNA was prepared for pyrosequencing using the PCR protocol described above except that $1 \mathrm{ng}$ template DNA was included in each reaction and the annealing temper- ature was $50^{\circ} \mathrm{C}$ to adjust for the $T_{\mathrm{m}}$ of the primers. Primers ('JRF': 5'-CGC AAG (A/G) HTR AAA CTC AAA GG-3' and 'JRR': 5'-ACT AGC GAH TCC (G/A) RCT TC-3') were designed with the program PRIMROSE (Ashelford et al. 2002) using the release 8.1 of the Ribosomal Database Project (RDP; Cole et al. 2009) to span the V5-V7 hypervariable regions and fused with 1 of 4 barcodes: 5'-CAG ATC G-3', 5'AGC TAG CT-3'. 5'-GTC AGT ACA-3', and 5'-TCG ACA GAT C- $3^{\prime}$. Analysis of the above primers using the Probe Match program at RDP resulted in $75 \%$ (JRF) and $85 \%$ (JRR) matches to all sequences ( $\geq 1200$ nucleotides, 1 error allowed) in the database. PCR products were pooled in equal proportion (to obtain a similar number of 454-pyrosequencing reads per sample) and sequenced on a Roche 454 GS-FLX pyrosequencer using Titanium chemistry at the Virginia Commonwealth University Nucleic Acids Research Facility (Richmond, Virginia). The following quality checks were implemented: primers trimmed, minimum sequence length 150, minimum exponential Q-score 20, and singletons included. Each rRNA query sequence was assigned to a set of hierarchical taxa using a naïve Bayesian rRNA classifier associated with RDP 10 Pyrosequencing Pipeline (Wang et al. 2007).

\section{Statistics}

For the field study, bacteria abundance estimates (total, live, and the proportion active [CTC+]) were related to environmental parameters by simple linear regression with Sidak-corrected significance levels (R statistical package). Overall spatial and temporal patterns in the environmental data were visualized using principal components analysis (PCA) applied to the correlation matrix (PAST statistical package; Hammer et al. 2001). For microcosm samples, treatment differences in $\mathrm{BA}, \mathrm{NPP}, \mathrm{CR}$, and chl a were each examined using 1-way ANOVA followed by a Tukey-Kramer HSD test for posthoc comparisons (JMP Version 8). For both sets of experiments, TRFLP data were analyzed using non-metric multidimensional scaling (NMDS) via the Jaccard similarity coefficient (PC-ORD Version 5; Kruskal 1964, Mather 1976).

For pyrosequencing data, RDP classifications (hereafter referred to as 'taxa') were applied with $85 \%$ of sequences being assigned to phyla, $81 \%$ to classes, and $38 \%$ to genus. From this information, diversity was calculated using the Chao1 estimator, and evenness was calculated as diversity divided by 
the natural log of richness (EstimateS, Version 7.5, R. K. Colwell). Similarity between $16 \mathrm{~S}$ rRNA and rDNA sequence libraries was visualized by NMDS with the Sorensen distance measure, and subsequently tested using the multiple response permutation procedure (MRPP, R statistical package). To assess the level of similarity between duplicate libraries, Sorensen distance measures were derived and compared against a reference distribution of distance measures from all possible pairwise comparisons of non-replicate samples. Replicated libraries for the May and August DNA samples were highly similar (Sorensen distances in the bottom 1\% and $10 \%$ of reference distribution, respectively) whereas the RNA replicates exhibited somewhat greater dissimilarity (Sorensen distances in the bottom 25\%).

Following Jones \& Lennon (2010), we assessed activity levels for individual taxa based on their relative contribution to 16S rRNA and rDNA libraries. This metric uses the relative contribution to each library (i.e. rRNA\%:rDNA\%) to avoid potential bias arising from differences in the number of sequences obtained from each sample. The relationship between rDNA-based rank and taxon-specific activity state was tested by binomial logistic regression (JMP 8). Sequence data have been submitted to the GenBank database under accession no. SRA034876.

\section{RESULTS}

\section{Field study}

The study period was characterized by warm water temperatures $\left(18\right.$ to $\left.30^{\circ} \mathrm{C}\right)$ and declining river discharge $\left(\right.$ May $=541 \mathrm{~m}^{3} \mathrm{~s}^{-1}$, September $=34 \mathrm{~m}^{3} \mathrm{~s}^{-1}$ ). When discharge was high (May), nutrients, DOC, chl $a, \mathrm{BA}$, and rates of metabolism (NPP, CR) were similar at the 2 sites (Fig. 1). As discharge declined, inter-site differences became apparent with JMS75 exhibiting lower inorganic nutrient concentrations (DIN, SRP) and higher chl $a$, BA, NPP, CR and DOC. At JMS75; average (May to September) chl a was 5-fold higher $\left(79 \pm 17\right.$ vs. $\left.15 \pm 5 \mu \mathrm{g} \mathrm{l}^{-1}\right)$, NPP was 6-fold higher $\left(696 \pm 154\right.$ vs. $\left.106 \pm 57 \mu \mathrm{g} \mathrm{O} \mathrm{l}^{-1} \mathrm{~h}^{-1}\right)$, and live BA was 2 -fold higher $\left(80 \pm 39 \times 10^{6}\right.$ vs. $27 \pm$ $7 \times 10^{6}$ cells $\mathrm{ml}^{-1}$ ) in comparison to JMS99. There were no significant differences between sites in the proportions of live $(p=0.46)$ or active $(p=0.21)$ cells determined by staining and enumeration (paired $t$ tests). On average, $84 \%$ of cells at both sites were 'alive' (intact membranes) while the proportion of metabolically 'active' (CTC+) cells corresponded to
$8 \%$ of live cells. Linear regression of logarithmically transformed data showed that total, live, and active bacterial abundances were significantly correlated with chl $a, \mathrm{NPP}, \mathrm{CR}$, and DOC (all $\mathrm{p} \leq 0.02$, all $\mathrm{R}^{2}$ $\geq 0.64)$.

When PCA was applied to the environmental data (Fig. 2), differences between the 2 sites were apparent from discrete distributions along PC1 $(42 \%$ of variation), which had high factor loadings for chl $a_{\text {, }}$ NPP, and CR $(\geq \pm 0.85)$. A temporal progression was observed along PC2 (29\% of variation), which corresponded strongly with changes in specific conductivity and turbidity (loadings $>0.75$ ). Overall, environmental conditions at the 2 sampling sites were most similar in May but diverged as chl $a$, NPP and CR increased at JMS75. These results contrast those of the TRFLP, where the NMDS ordination (2D solution; stress $=0.20$, combined $R^{2}=0.56$ ) did not reveal differences in the bacterial communities at the 2 sites. A modest temporal progression was observed in community composition along Axis 1, and was consistent across sites. Overall, these findings show that while environmental parameters and BA differed between the 2 sites, CTC-based estimates of activity state and TRFLP-based assessments of community similarity did not.

\section{Microcosm experiments}

At the low-nutrient and high-chl a site (JMS75), both the 'Nutrient' and 'Combined' treatments resulted in significant increases in chl $a, \mathrm{NPP}$, and live BA ( $p<0.05$ via 1 -way ANOVA; Fig. 3). However, the 'Nutrient' and 'Combined' treatments were never significantly different from each other.

For both sites, the proportion of cells that were metabolically active (CTC+) was not responsive to any treatment, nor was CR. NMDS of the TRFLP data did not show a clear separation of sites or treatments (results not presented), and no significant differences were detected using an analysis of similarity (ANOSIM; all $\mathrm{p} \geq 0.10$ ). Overall, these results indicate that resource amendments had significant effects on BA, but not TRFLP-based assessments of community composition or CTC-based estimates of activity state.

\section{Pyrosequencing results}

After trimming sequences and discarding poor reads, 156872 sequences were obtained from 32 

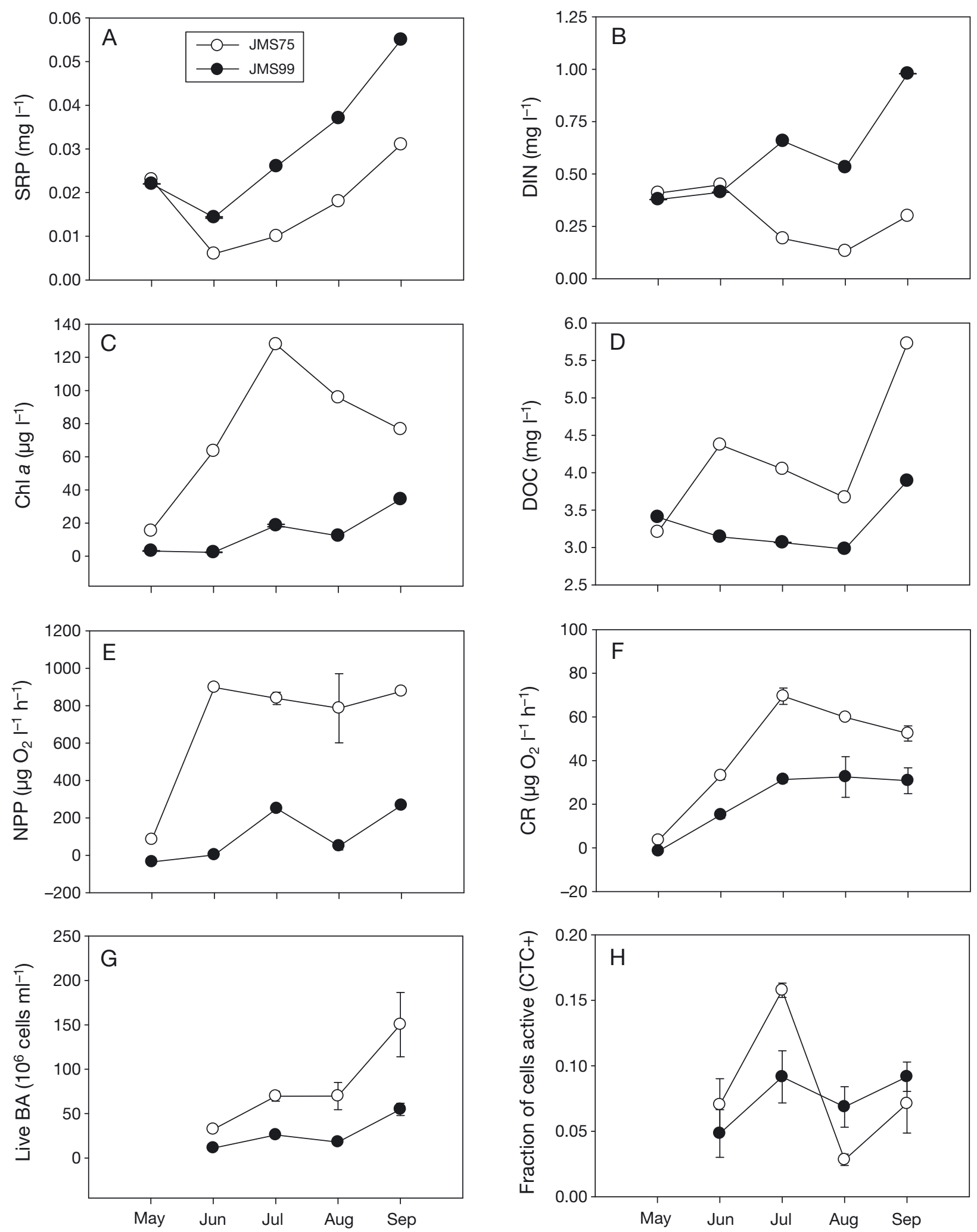

Fig. 1. (A) Soluble reactive phosphorus (SRP), (B) dissolved inorganic nitrogen (DIN), (C) phytoplankton biomass (chl a), (D) dissolved organic carbon (DOC), (E) net primary production (NPP), (F) community respiration (CR), (G) abundance of live bacterial cells (BA), and (H) the fraction of intact cells that are active (CTC+) for 2 sites (JMS99 and JMS75) on the tidal freshwater James River. Error bars are $\pm 1 \mathrm{SE}(\mathrm{N}=3)$ 

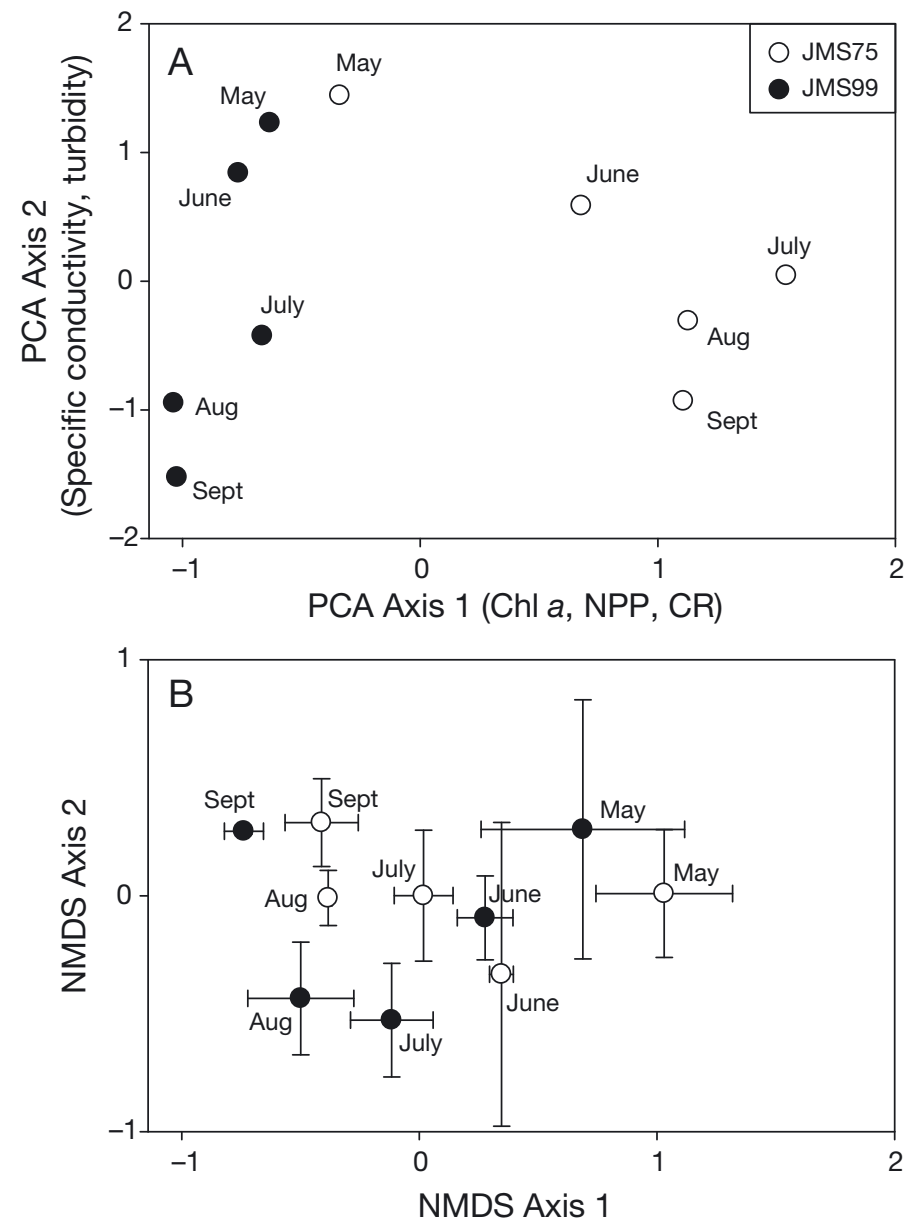

Fig. 2. (A) Principal components analysis (PCA) ordination of environmental conditions and (B) non-metric multidimensional scaling (NMDS) ordination of microbial community similarity based on terminal restriction fragment length polymorphism (TRFLP) for 2 sites in the tidal freshwater James River (JMS99 and JMS75). PCA Axis 1 explains 42\% of variation with high factor loadings for phytoplankton biomass (chl a), net primary production (NPP), and community respiration (CR). PCA Axis 2 explains $29 \%$ of variation with high factor loadings for specific conductivity and turbidity. NMDS explains $56 \%$ of variation in TRFLP peak profiles (stress $=0.20)$. Error bars are $\pm 1 \mathrm{SE}(\mathrm{N}=3)$

samples with an average length of $410 \mathrm{bp}$. Sampling depth was somewhat greater for rDNA libraries $(5224 \pm 295$ sequences per sample; mean $\pm \mathrm{SD})$ than for rRNA libraries $(4489 \pm 229)$. Rarefaction curves exhibited a marked decrease in slope at 1000 (DNA) and $~ 500$ (RNA) sequences indicating that sampling was sufficient to identify the dominant community members as well as many rare taxa (see Fig. $\mathrm{S} 1$ in the Supplement at www.int-res.com/articles/suppl/a069 p247_supp.pdf). Based on RDP classifications, the average number of taxa in the 16S rDNA libraries $(147 \pm 5)$ was higher than in the rRNA libraries
$(127 \pm 7)$. rDNA-based libraries also had significantly higher evenness relative to rRNA libraries ( $p=0.02$; 1-way ANOVA; Table 1). For both rDNA and rRNA libraries, samples from JMS99 exhibited higher diversity than samples from JMS75 (Fig. 4). The total number of taxa found within paired rRNA-rDNA libraries averaged $181 \pm 6$ for all sites, months, and treatments. The proportion of taxa that occurred in the rDNA library but not the corresponding rRNA library was $31 \pm 2 \%$, the proportion of taxa that occurred in the rRNA library but not the rDNA library was $19 \pm 2 \%$, and $50 \pm 1 \%$ of taxa were found in both of the paired samples.

For the field samples, NMDS of the 16S rRNA and rDNA libraries revealed discrete distributions in ordination space (Fig. 5A), which were significantly different via MRPP $(p=0.002)$. This suggests that the composition of the metabolically active fraction of the bacterial community (i.e. those assessed via 16S rRNA) differed from that of the overall community (assessed via 16S rDNA). The rRNA libraries also exhibited greater dispersion among samples indicating greater compositional variability among active taxa. With the exception of May and 1 of the June samples, the rDNA libraries were tightly clustered showing little spatial or temporal variation. For rRNA libraries, significant variation was observed by month ( $\mathrm{p}=0.04$; MRPP) but not by site $(p=0.33)$. For both rDNA and rRNA libraries, Cyanobacteria and Betaproteobacteria were the dominant classes, accounting for $40 \%$ of rDNA sequences from environmental samples (see Fig. S2 in the Supplement). Sphingobacteria were also moderately abundant at both sites. Cyanobacterial numbers climbed throughout the summer at both JMS75 and JMS99. Betaproteobacteria peaked in August at JMS75 and then dropped in September, even while Cyanobacteria continued to increase. Betaproteobacteria peaked at JMS99 in June with a relative abundance of $75 \%$, whereas Cyanobacteria appeared to be a major component of increasing bacterial density in late summer. In environmental samples, $48 \%$ of those rDNA sequences identified as Betaproteobacteria were classified as Burkholderiales and another $37 \%$ were unclassified. Of those rDNA sequences identified as Cyanobacteria, $96 \%$ were unclassified Deferribacterales. Cyanobacteria Family 1.1 always accounted for a disproportionate number of rRNA sequences with $35 \%$ of Cyanobacteria sequences attributed to Prochlorococcus.

In the microcosm samples, rDNA and rRNA libraries were also well-separated using NMDS (Fig. 5B). 
JMS75
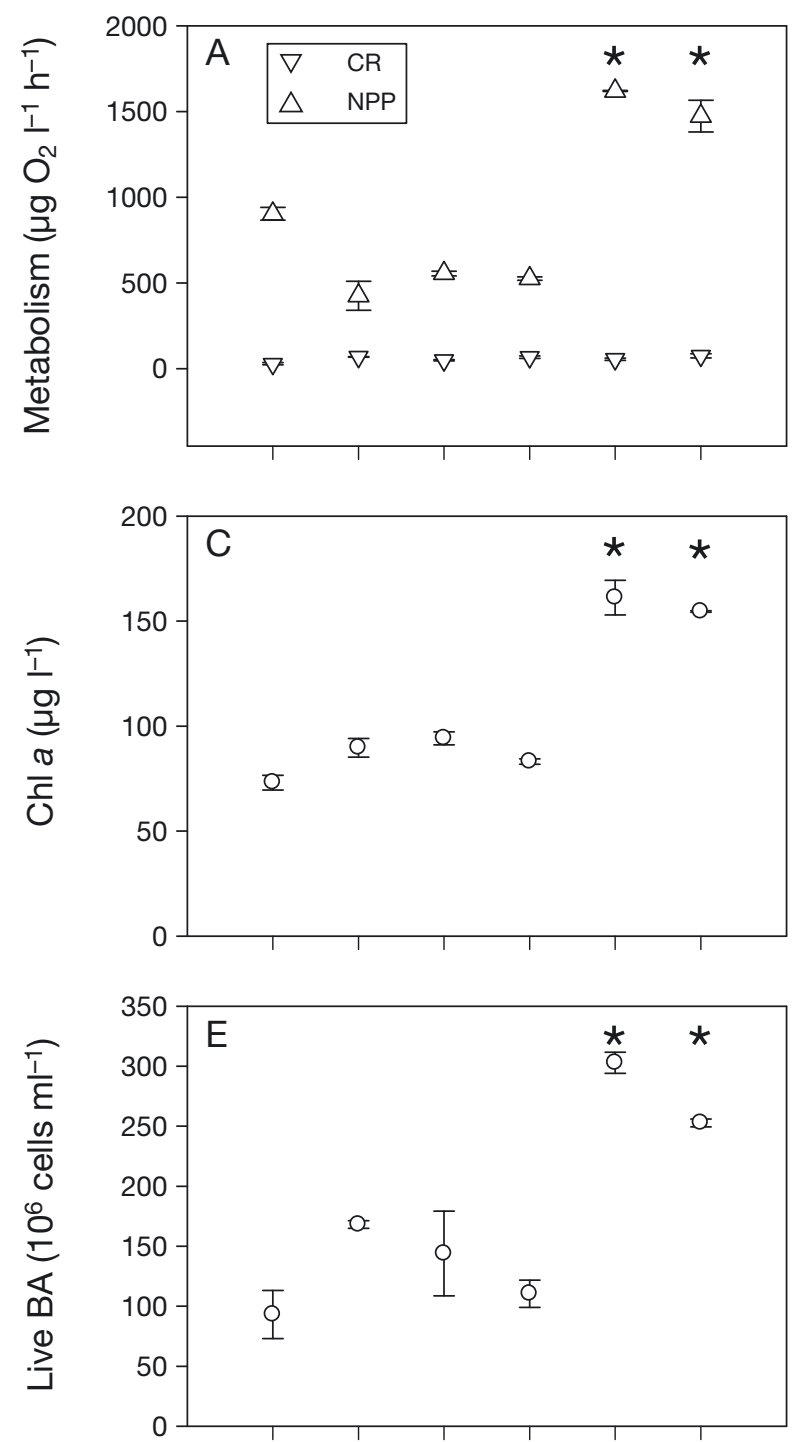

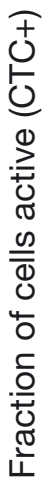

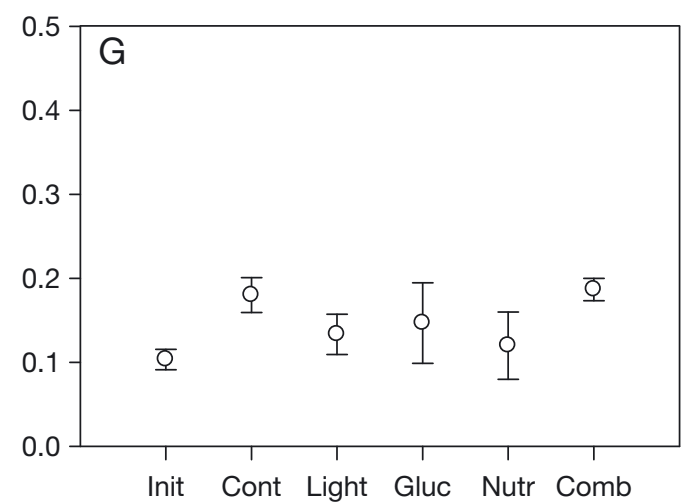

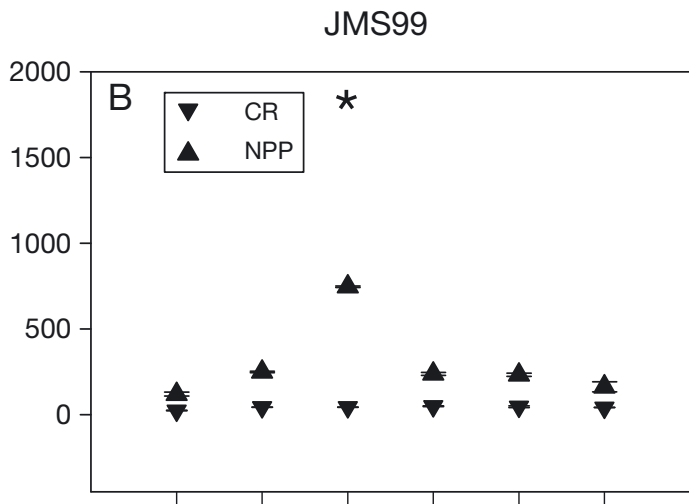
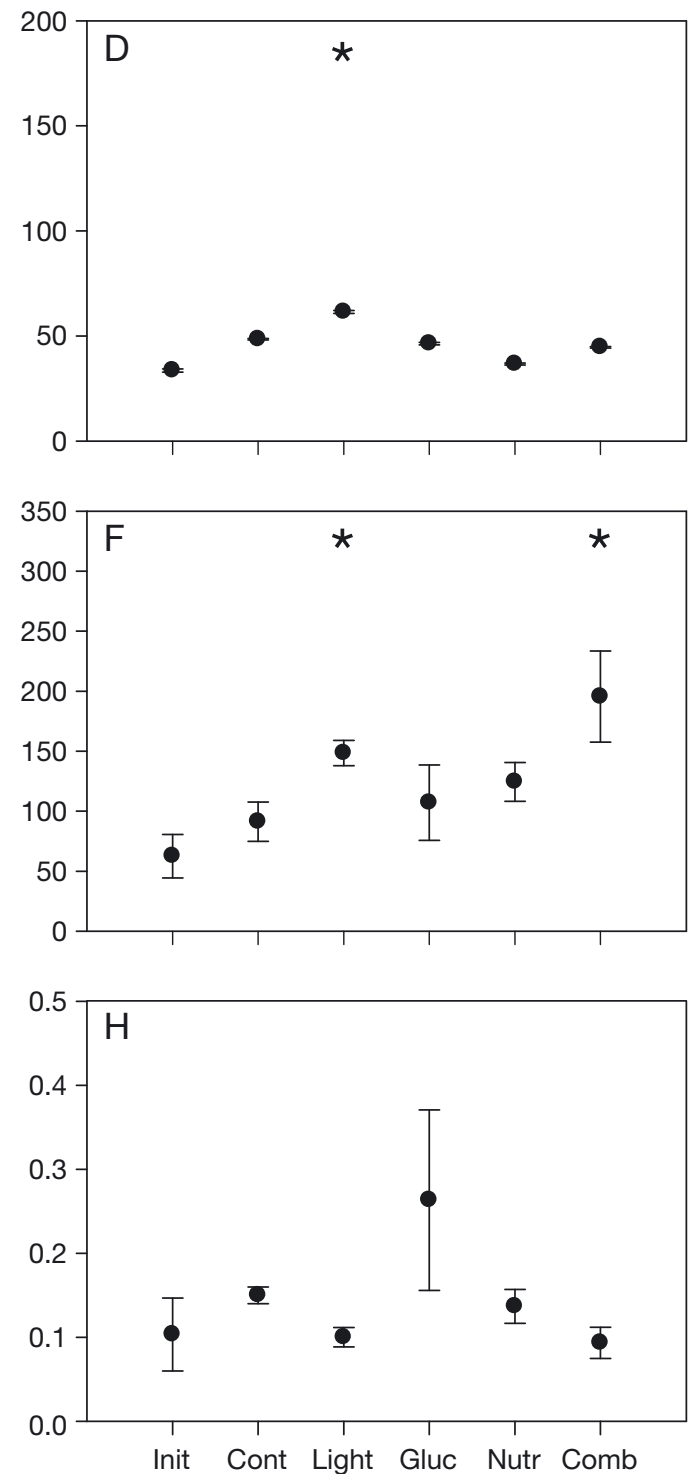

Fig. 3. Effects of resource amendments on $(A, B)$ net primary production (NPP) and community respiration $(C R)$, $(C, D)$ phytoplankton biomass (chl a), (E,F) live bacterial abundance (BA), and $(\mathrm{G}, \mathrm{H})$ fraction of live cells that are metabolically active for 2 sites (JMS75 and JMS99) in the tidal freshwater James River. Init = Initial (pre-incubation), Cont = Control, Light, Gluc $=$ Glucose, Nutr $=$ Nutrients, and Comb $=$ Combined (nutrients + light + glucose). Error bars are $\pm 1 \mathrm{SE}(\mathrm{N}=3)$. * Treatments that were significantly different $(\mathrm{p}<0.05)$ from the Control 
Table 1. rDNA and rRNA pyrosequencing results for environmental and experimental (microcosm) samples obtained from 2 stations in the tidal freshwater James River (JMS75, JMS99). Data shown are the number of taxa, evenness, and diversity (Chao1) of rDNA and rRNA libraries as well the proportion of active taxa and the proportion of active cells inferred from rRNA and rDNA relative abundance ratios (rRNA\%:rDNA \% >1). nd = not determined

\begin{tabular}{|c|c|c|c|c|c|c|c|c|}
\hline \multirow[t]{2}{*}{ Sample } & \multicolumn{3}{|c|}{ rDNA libraries $\longrightarrow$} & \multirow{2}{*}{$\overline{\text { Taxa }}$} & \multicolumn{2}{|c|}{ rRNA libraries } & \multicolumn{2}{|c|}{ Activity (rRNA:rDNA) } \\
\hline & Taxa & Evenness & Diversity & & Evenness & Diversity & Taxa (\%) & Cells (\%) \\
\hline \multicolumn{9}{|c|}{ Environmental } \\
\hline \multicolumn{9}{|c|}{ JMS75 } \\
\hline May & 176 & 0.66 & 195 & 148 & 0.68 & 253 & 54 & 15 \\
\hline June & 144 & 0.66 & 307 & 125 & 0.60 & 328 & 52 & 32 \\
\hline July & 159 & 0.67 & 344 & 105 & 0.63 & 354 & 42 & 41 \\
\hline August & 139 & 0.70 & 368 & 150 & 0.59 & 380 & 69 & 50 \\
\hline September & 152 & 0.64 & 418 & 107 & 0.61 & 430 & 42 & 38 \\
\hline \multicolumn{9}{|l|}{ JMS99 } \\
\hline May & 173 & 0.64 & 482 & nd & nd & nd & nd & nd \\
\hline June & 94 & 0.55 & 492 & nd & nd & nd & nd & nd \\
\hline July & 147 & 0.68 & 495 & 169 & 0.68 & 502 & 78 & 34 \\
\hline August & 164 & 0.66 & 506 & nd & nd & nd & nd & nd \\
\hline September & 143 & 0.64 & 512 & 138 & 0.68 & 516 & 66 & 10 \\
\hline \multicolumn{9}{|l|}{ Microcosm } \\
\hline \multicolumn{9}{|l|}{ JMS75 } \\
\hline Control & 154 & 0.71 & 438 & 142 & 0.56 & 449 & 47 & 26 \\
\hline Nutrient & 136 & 0.71 & 456 & 102 & 0.60 & 462 & 42 & 21 \\
\hline Combined & 118 & 0.69 & 470 & 80 & 0.59 & 478 & 27 & 45 \\
\hline \multicolumn{9}{|l|}{ JMS99 } \\
\hline Control & 134 & 0.72 & 522 & 154 & 0.68 & 530 & 75 & 43 \\
\hline Nutrient & 163 & 0.71 & 529 & 117 & 0.69 & 531 & 39 & 29 \\
\hline Combined & 122 & 0.70 & 536 & 106 & 0.58 & 537 & 50 & 39 \\
\hline
\end{tabular}

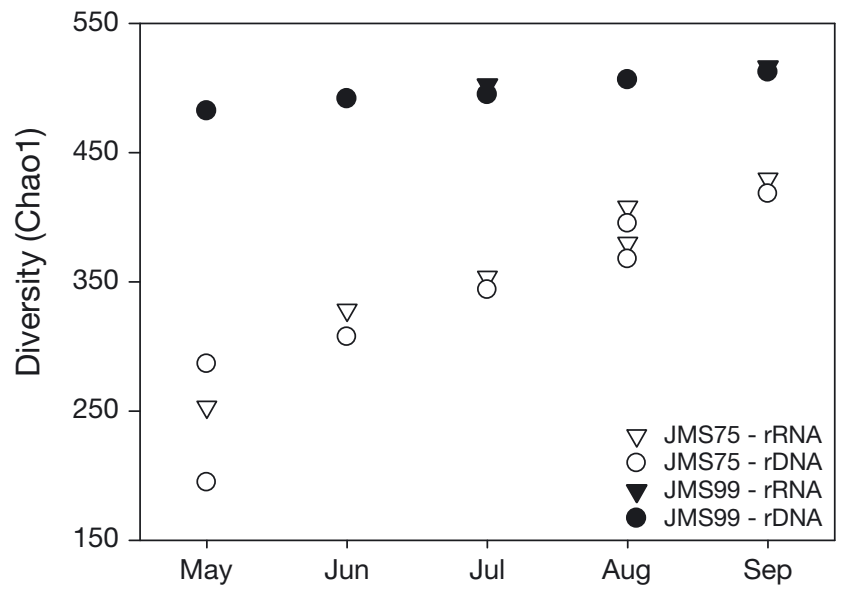

Fig. 4. Monthly variation in the diversity of bacterioplankton communities at 2 stations in the tidal freshwater James River based on rDNA and rRNA pyrosequencing. Duplicate points denote replicated rDNA (May, August) and rRNA (August) libraries

As was observed in the analysis of field samples, the rDNA libraries for JMS75 and JMS99 were similar, but the rRNA libraries were not. For each site and each library type (rRNA or rDNA), there were con- sistent shifts in community composition along Axis 1 (59\% of variation) in response increasing resource amendments (Control $\rightarrow$ Nutrients $\rightarrow$ Combined). Differences in community composition between Control and Combined treatments were statistically significant for the pooled (both sites) dataset ( $p=$ 0.006; MRPP). In response to the Combined treatment, samples for both sites became more similar. Increasing Betaproteobacteria was an important contributor to the overall increase in bacterial abundance in the microcosm samples. Betaproteobacteria were only moderately abundant in initial samples $(\sim 15 \%)$, but became dominant in the combined treatment microcosms $(50 \%)$. Although Burkholderiales were important in environmentally derived rDNA libraries, Neisseriaceae, primarily Chromobacteria, were more prominent in the experiments, accounting for over $40 \%$ of betaproteobacterial sequences and over $20 \%$ of all bacterial sequences in both the JMS75 and JMS99 combined treatment microcosms.

Individual taxa were categorized as active or inactive based on their relative contribution to rRNA and rDNA libraries (rRNA\%:rDNA \% >1). The pro- 


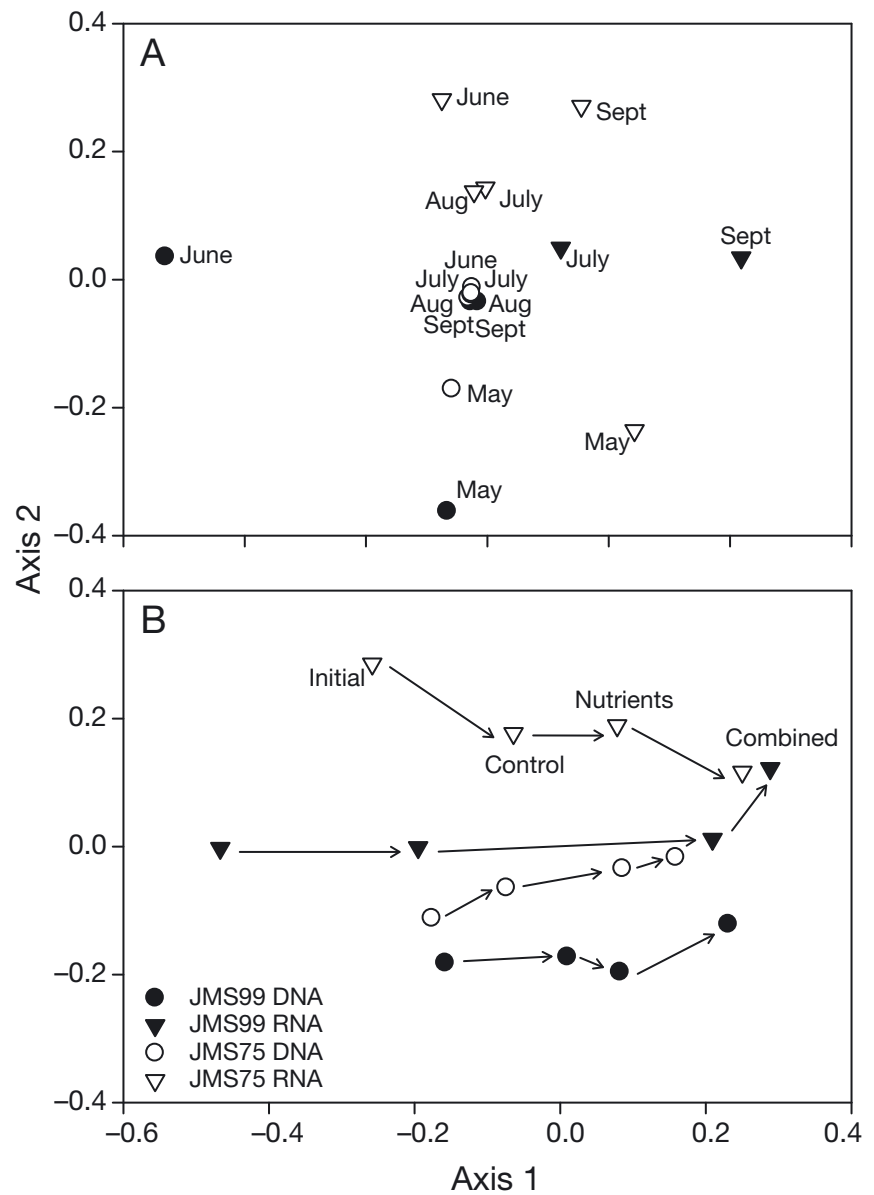

Fig. 5. Ordination (NMDS) of 16S rDNA and rRNA sequence libraries for (A) environmental samples obtained from 2 sites in the tidal freshwater James River (cumulative $R^{2}=0.82$ ) and from (B) September microcosm experiments performed at these sites (cumulative $\mathrm{R}^{2}=0.80$ ). Arrows in lower panel denote progression from Initial to Control, Nutrient, and Combined treatments

portion of active taxa ranged from 27 to $78 \%$ (mean $=52 \pm 4 \%$; Table 1) among all samples. Neither site nor month was found to be a significant explanatory variable for variation in the proportion of active taxa among environmental samples (ANOVA, $p>0.20$ ). Binomial logistic regression showed that for each drop in rDNA-based rank, the odds ratio of a taxa being active increased by $1.01 \pm 0.001$ (Fig. $6 ; \mathrm{p}<$ 0.0001; environmental and microcosm libraries pooled). This finding suggests that rare taxa were more likely to be active. Weighting active taxa according to their contribution to the $16 \mathrm{~S}$ rDNA library yielded an estimate of $32 \pm 3 \%$ of sequences that were derived from active cells (average for all environmental and microcosm samples). However, this estimate was sensitive to the presumed threshold for distinguishing active cells (rRNA\%:rDNA\%
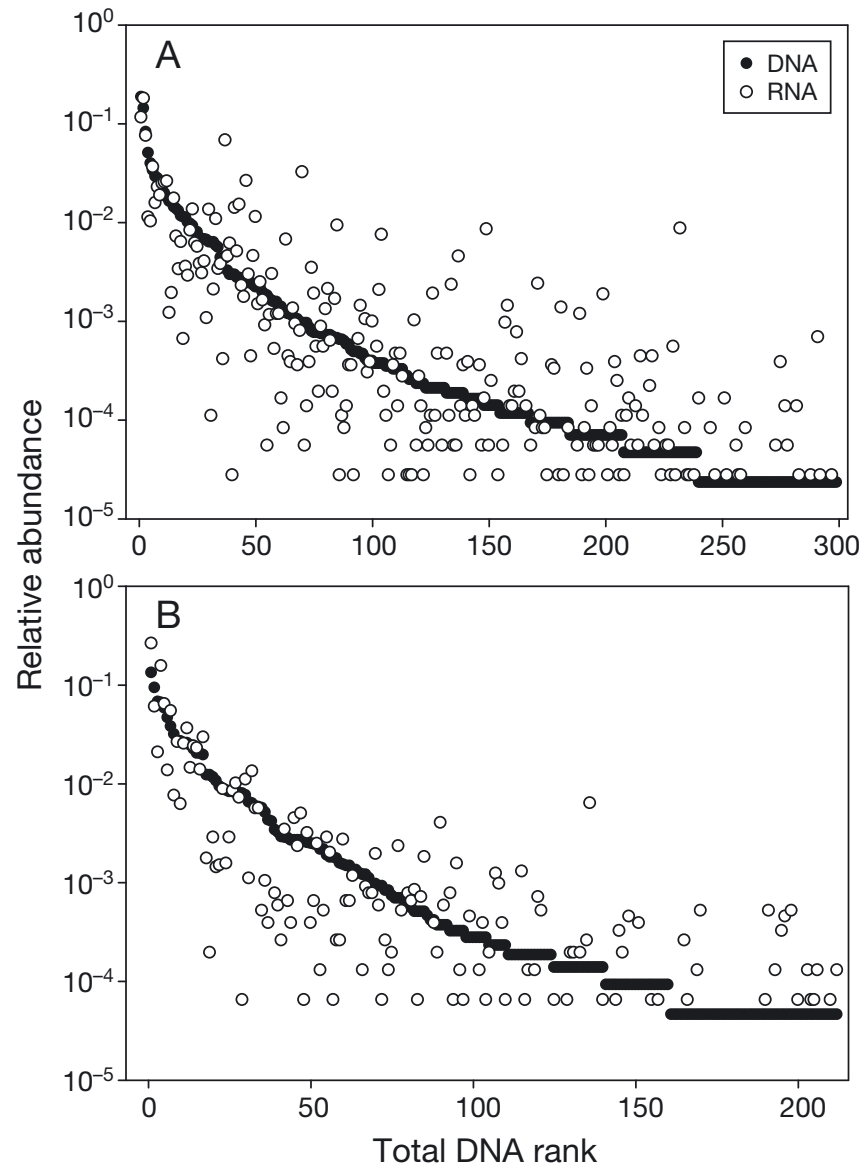

Fig. 6. Taxon-specific contributions to rRNA and rDNA libraries show that taxa which are low in the DNA hierarchy are more likely to be active (rRNA\% > DNA\%). Data shown are for taxa represented in both rRNA and rDNA libraries for the (A) environmental samples obtained from 2 sites in the tidal freshwater James River and (B) September microcosm experiments performed at these sites

$>1$; Jones \& Lennon 2010). For example, use of a higher threshold (rRNA:rDNA > 2) indicated that only $7 \pm 1 \%$ of sequences were derived from active cells. Results from microcosm experiments show that resource amendments resulted in fewer active taxa but a greater number of active cells (Fig. 7). That is, the amendments increased the proportion of active cells but this response was limited to a small subset of the community. Bacterial orders that were consistently under-represented in rRNA libraries relative to rDNA libraries included Actinobacteria, Planctomycetacia, and Flavobacteria (see Fig. S3 in the Supplement). Other orders exhibited variable activity state, each including a few samples with disproportionately high contributions to rRNA libraries relative to rDNA libraries (see Fig. S4 in the Supplement). 

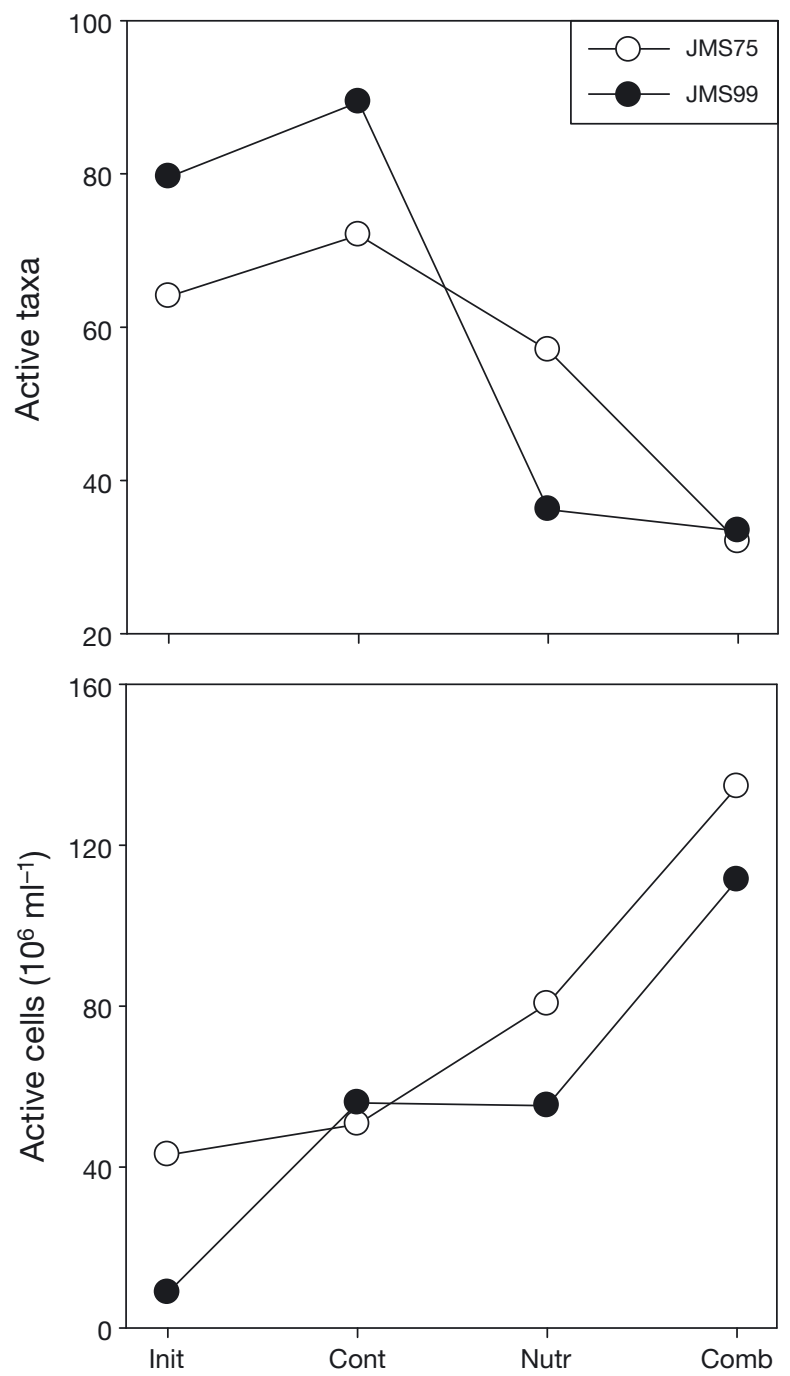

Fig. 7. Microcosm experiments using bacterioplankton obtained from 2 stations in the tidal freshwater James River showed that (A) the number of active taxa declined, while (B) the number of active cells increased in response to resource amendments (abbreviations as in Fig. 3)

\section{DISCUSSION}

Our use of dual 16S rDNA-rRNA pyrosequencing combined with traditional microscopic analysis provided a novel basis for examining bacterioplankton abundance, composition, and activity state under variable resource conditions. Relationships were tested via field study at 2 sites with contrasting resource availability, and via microcosms in which resources were experimentally manipulated. Overall, our results indicate that the large abundance of inactive taxa in bacterial communities can affect TRFLP- and rDNA-based assessments of microbial community responses to changing resource condi- tions. Our rRNA pyrosequencing revealed that unique assemblages of active taxa may exist in variable resource conditions, despite similarities in overall community composition (i.e. DNA-based assays).

In our field study, bacterial abundance (both live and active) correlated strongly and positively with chl $a$, NPP, and DOC, which suggests that algal exudates may be an important source of labile organic matter stimulating the growth and production of estuarine bacteria (Lancelot \& Billen 1984, Cole et al. 1988, White et al. 1991). This proposition is supported by the results of a related study that revealed higher quality of DOC (lower C:N) and faster turnover of DOC at the JMS75 site (Bukaveckas et al. 2011), where consistently high levels of chl a were observed. Given the large differences in nutrient concentrations, organic matter quality, and bacterial abundance between JMS75 and JMS99, we hypothesized that analysis of bacterial community composition (i.e. DNA-based assays) would reveal distinct assemblages in the 2 sites. However, despite these inter-site differences in resource availability, both TRFLP and pyrosequencing revealed high similarity in bacterial community composition across sites. Prominent taxa in our samples were typical of the freshwater environment, with a few exceptions. For example, we observed a high prevalence of Cyanobacteria, supporting previous work showing that density of Cyanobacteria is higher in the tidal-freshwater James River than in other Chesapeake Bay tributaries (Marshall et al. 2009). In contrast, although Bacteroidetes are common in other studies, the prevalence of Sphingobacteria in our environmental samples was unusually high. Overall, our findings suggest that bacterial abundance was most closely linked to autochthonous production, which varied between sites and likely influenced the quantity and quality of organic matter. However, bacterial response to the resource gradient between JMS75 and JMS99 does not appear to have involved a shift in community composition or changes in active bacterial abundance. The fact that communities were similar despite differences in environmental conditions could be attributed to short transit times between these 2 sites, if water moves between sampling sites faster than the microbial community can respond via shifts in community structure. However, transit times for this segment of the James River were previously estimated to be $15 \mathrm{~d}$ (at the annual average discharge: $200 \mathrm{~m}^{3} \mathrm{~s}^{-1}$; Shen \& Lin 2006, Shen et al. 1999). During a portion of our study, actual transit times were longer (July, August, and September discharge $<100 \mathrm{~m}^{3} \mathrm{~s}^{-1}$ ), making it unlikely that short 
transit time precluded community differentiation. Rather, our findings are consistent with several recent studies showing that rDNA-based assessments of community composition can exhibit a high degree of similarity owing to the large proportion of inactive cells and the widespread distribution of dominant taxa (Sloan et al. 2006, Woodcock et al. 2007, Östman et al. 2010). In our samples, $~ 30 \%$ of taxa occurring within 16S rDNA libraries were not found in corresponding rRNA libraries.

The microcosm experiment demonstrated a differential effect of resource amendments on the microbial communities from these 2 sites. The results were consistent with the hypothesis that the in situ microbial communities at JMS75 are nutrient limited and those at JMS99 are light limited. These expectations are based on historical knowledge of the longitudinal trends in dissolved nutrients and light availability associated with this portion of the river (Bukaveckas et al. 2011) as well as site morphology. For example, JMS99 is located in a deeper segment of the river where underwater irradiance and NPP are low, and microbial communities responded most in the enhanced light. Interestingly, for both sites, treatment effects were linked to higher levels of live bacterial abundance, chl $a$, and NPP, but did not change community composition. TRFLP revealed no consistent treatment effect for either site, and pyrosequencing of the rDNA showed differences only when the most extreme treatments were compared (e.g. Control and Combined). For example, Chromobacteria had $<1 \%$ relative abundance in Initial samples and $>20 \%$ relative abundance in the Combined treatment. These modest changes in community composition were not accompanied by changes in diversity or evenness (Table 1). However, as was the case with the field study, pyrosequencing of the rRNA provided a very different picture of bacterial community dynamics. Results from the rRNA libraries showed greater differences between sites (e.g. compare 'Initial' treatments from JMS75 and JMS99) and more dramatic changes in community composition compared to that provided by the rDNA libraries. This is further evidence that community-level assessment of DNA may be biased towards the most abundant members of the community, which are not necessarily the most active.

Across both the field and microcosm studies, we observed large changes in bacterial abundance despite the low proportion of the community considered active based on CTC staining. CTC-based estimates for the abundance of active cells have been shown to correlate with bacterial production (del Giorgio et al. 1997, Sherr et al. 1999) and respiration
(Smith 1998), but have also come under criticism for possible methodological constraints (e.g. Ullrich et al. 1996, Karner \& Fuhrman 1997, Servais et al. 2001, Créach et al. 2003). In our study, the percentage of cells identified as active based on CTC staining was low (mean $=13 \pm 1 \%$ ), but similar to previously reported values (del Giorgio \& Scarborough 1995, Choi et al. 1996, 1999, Karner \& Fuhrman 1997). If only CTC+ cells were actively dividing, maximum doubling times in our microcosms ranged from 8 to $21 \mathrm{~h}$, consistent with values derived from bacterial production measurements (Crump et al. 2007). CTCbased estimates of cell activity were not found to be responsive to environmental or experimental variations in resource conditions. In contrast, assessments of activity state based on 16S rRNA sequencing yielded higher estimates of the proportion of active cells $(32 \pm 3 \%)$ and revealed greater variability among environmental (sites, months) and experimental (Control, treatments) samples. Our basis for determining activity state followed Jones \& Lennon (2010), whereby taxa with a higher relative abundance of rRNA than rDNA were considered 'active' (ratio > 1). An inherent limitation to this approach is the variable rRNA operon copy numbers among taxa. Even more noteworthy is the fact that bacteria likely exhibit a continuum of activity levels such that the use of a fixed threshold to distinguish 'active' from 'inactive' is subjective; it may be more appropriate to instead view cellular metabolism as a continuum within a nested hierarchy of physiological states (Smith \& del Giorgio 2003). Within this conceptual model, the method described above provided a basis for delineating the active fraction that may prove useful to understanding how environmental conditions shape bacterial communities and for linking changes in the active component to specific functions of interest (Mou et al. 2008, DeLong 2009, McCarren et al. 2010).

Despite problems in defining 'active' taxa, the disparity found between 16S rRNA libraries, even when their corresponding rDNA libraries were similar, emphasizes the differences in composition between the overall community and its active fraction. For example, rDNA libraries indicated that bacterial communities at JMS75 and JMS99 were largely unchanged throughout the second half of our sampling period, whereas rRNA libraries varied greatly from site to site and from month to month. In September, rDNA libraries from the 2 sites exhibited a high degree of similarity (Sorensen distance in lower $10 \%$ ), while rRNA libraries had low similarity (Sorensen distance in top 15\%). It should be noted 
that even replicate rRNA libraries showed somewhat greater dissimilarity (lower 25\%-tile) than replicate rDNA libraries (lower 10\%-tile). Greater dissimilarity may be due to lower sampling depth for the rRNA duplicates or to methodological issues related to rRNA recovery and cDNA production. These findings are based on a single replicated rRNA sample and 2 replicated rDNA samples, but suggest that further efforts are needed to resolve the reproducibility of rRNA libraries.

Our principal finding was that 16S rRNA libraries differed from rDNA libraries obtained from the same site/month or microcosm. Further, rRNA libraries were more variable in composition than rDNA libraries. While the majority of taxa $(\sim 50 \%)$ were represented in both rRNA and rDNA libraries, a large proportion $(30 \%)$ contributed to rDNA libraries but not rRNA. Another $20 \%$ of taxa contributed to rRNA but were too rare to be detected among rDNA sequences. These patterns suggest that environmental conditions select unique subsets of active taxa from a common pool of taxa. Our results also show that rare taxa were more likely to be active than dominant taxa. This has previously been demonstrated for estuarine or marine bacteria taking up specific substrates (e.g. Cottrell \& Kirchman 2000, Alonso-Sáez et al. 2007, Ruiz-González et al. 2012), but research at the community level is only just beginning (Jones \& Lennon 2010, Sjöstedt et al. 2012). Disproportionate activity by rare taxa dispels the notion that rare taxa are present 'accidentally' and supports the theory that they represent an important component of the community capable of exploiting favorable environmental conditions. Dominant taxa are presumably very competitive generalists whose prominence manifests in a high degree of similarity in rDNA assessments of community composition. Rare taxa contribute the bulk of community diversity and account for a larger proportion of the active community than would be expected based on their relative abundance. The extent to which the uneven distribution of taxa and variable activity state determines how microbial communities control rates of ecosystem processes, and their ability to respond to environmental disturbances, is an important avenue for future research.

Acknowledgements. We are grateful to C. Frederickson and the James River Association for assistance with field sampling, the VCU Rice Center for a student research grant to C. Luria, Dr. Thomas Huff (VCU Life Sciences) for providing funds for pyrosequencing, J. Alves and N. Seth for assistance with the sequence data, and the VCU Graduate
School for providing a Thesis Fellowship to C.L. P.A.B. was supported as a Fulbright scholar at the Klaipeda University Coastal Research and Planning Institute during the writing phase of this project. This paper is contribution number 35 to the VCU Rice Center.

\section{LITERATURE CITED}

Alonso-Sáez L, Arístegui J, Pinhassi J, Gómez-Consarnau L and others (2007) Bacterial assemblage structure and carbon metabolism along a productivity gradient in the NE Atlantic Ocean. Aquat Microb Ecol 46:43-53

Ashelford KE, Weightman AJ, Fry JC (2002) PRIMROSE: a computer program for generating and estimating the phylogenetic range of $16 \mathrm{~S}$ rRNA oligonucleotide probes and primers in conjunction with the RDP-II database. Nucleic Acids Res 30:3481-3489

Azam F, Fenchel T, Field JG, Gray JS, Meyer-Reil LA, Thingstad $F$ (1983) The ecological role of water-column microbes in the sea. Mar Ecol Prog Ser 10:257-263

Bakken LR, Olsen RA (1987) The relationship between cell size and viability of soil bacteria. Microb Ecol 13:103-114

Bouvier TC, del Giorgio PA (2002) Compositional changes in free-living bacterial communities along a salinity gradient in two temperate estuaries. Limnol Oceanogr 47: 453-470

Bukaveckas PA, Barry LE, Beckwith MJ, David V, Lederer B (2011) Factors determining the location of the chlorophyll maximum and the fate of algal production within the tidal freshwater James River. Estuar Coast 34: 569-582

Cherrier J, Bauer JE, Druffel ERM (1996) Utilization and turnover of labile dissolved organic matter by bacterial heterotrophs in eastern North Pacific surface waters. Mar Ecol Prog Ser 139:267-279

> Choi JW, Sherr EB, Sherr BF (1996) Relation between presence-absence of a visible nucleoid and metabolic activity in bacterioplankton cells. Limnol Oceanogr 41: 1161-1168

> Choi JW, Sherr BF, Sherr EB (1999) Dead or alive? A large fraction of ETS-inactive marine bacterioplankton cells, as assessed by reduction of CTC, can become ETS-active with incubation and substrate addition. Aquat Microb Ecol 18:105-115

Cole JJ (1999) Aquatic microbiology for ecosystem scientists: new and recycled paradigms in ecological microbiology. Ecosystems 2:215-225

Cole JJ, Findlay S, Pace ML (1988) Bacterial production in fresh and saltwater ecosystems: a cross-system overview. Mar Ecol Prog Ser 43:1-10

Cole JR, Wang Q, Cardenas E, Fish J and others (2009) The Ribosomal Database Project: improved alignments and new tools for rRNA analysis. Nucleic Acids Res 37(Suppl 1):D141-D145

> Cottrell MT, Kirchman DL (2000) Natural assemblages of marine proteobacteria and members of CytophagaFlavobacter cluster consuming low- and high-molecular weight dissolved organic matter. Appl Environ Microbiol 66:1692-1697

> Créach V, Baudoux AC, Bertru G, Le Rouzic B (2003) Direct estimate of active bacteria: CTC use and limitations. J Microbiol Methods 52:19-28

> Crump BC, Hopkinson CS, Sogin ML, Hobbie JE (2004) Microbial biogeography along an estuarine salinity gra- 
dient: combined influences of bacterial growth and residence time. Appl Environ Microbiol 70:1494-1505

- Crump BC, Peranteau C, Beckingham B, Cornwell JC (2007) Respiratory succession and community succession of bacterioplankton in seasonally anoxic estuarine waters. Appl Environ Microbiol 73:6802-6810

Dawes CJ (1988) The Winkler procedure for measurement of dissolved oxygen. In: Lobban CS, Chapman DJ, Kremer BP (ed) Experimental phycology: a laboratory manual. Cambridge University Press, New York, NY, p 78-82

del Giorgio PA, Gasol JM (2008) Physiological structure and single-cell activity in marine bacterioplankton. In: Kirchman DL (ed) Microbial ecology of the oceans, 2nd edn. John Wiley \& Sons, Hoboken, NJ

del Giorgio PA, Scarborough G (1995) Increase in the proportion of metabolically active bacteria along gradients of enrichment in fresh-water and marine plankton: implications for estimates of bacterial growth and production rates. J Plankton Res 17:1905-1924

del Giorgio PA, Prairie YT, Bird DF (1997) Coupling between rates of bacterial production and the abundance of metabolically active bacteria in lakes, enumerated using CTC reduction and flow cytometry. Microb Ecol 34:144-154

DeLong EF (2009) The microbial ocean from genomes to biomes. Nature 459:200-206

> Eiler A, Langenheder S, Bertilsson S, Tranvik LJ (2003) Heterotrophic bacterial growth efficiency and community structure at different natural organic carbon concentrations. Appl Environ Microbiol 69:3701-3709

Epstein SS (2009) Microbial awakenings. Nature 457:1083

- Freitag TE, Chang L, Prosser JI (2006) Changes in the community structure and activity of betaproteobacterial ammonia-oxidizing sediment bacteria along a freshwater-marine gradient. Environ Microbiol 8:684-696

Frette L, Jørgensen NOG, Nybroe O, Giorgio PAD, Kroer N (2009) Effect of availability of nitrogen compounds on community structure of aquatic bacteria in model systems. Microb Ecol 57:104-116

Gasol JM, Comerma M, Garcia JC, Armengol J, Casamayor EO, Kojecká P, Šimek K (2002) A transplant experiment to identify the factors controlling bacterial abundance, activity, production, and community composition in a eutrophic canyon-shaped reservoir. Limnol Oceanogr 47: 62-77

Hammer Ã, Harper DAT, Ryan PD (2001) PAST: Paleontological statistics software package for education and data analysis. Palaeontol Electronica 4:1-9

> Henriques IS, Almeida A, Cunha A, Correia A (2004) Molecular sequence analysis of prokaryotic diversity in the middle and outer sections of the Portuguese estuary Ria de Aveiro. FEMS Microbiol Ecol 49:269-279

Hoikkala L, Aarnos H, Lignell R (2009) Changes in nutrient and carbon availability and temperature as factors controlling bacterial growth in the Northern Baltic Sea. Estuar Coast 32:720-733

> Jones SE, Lennon JT (2010) Dormancy contributes to the maintenance of microbial diversity. Proc Natl Acad Sci USA 107:5881-5886

Jürgens K, Güde H (1994) The potential importance of grazing-resistant bacteria in planktonic systems. Mar Ecol Prog Ser 112:169-188

Kan J, Suzuki MT, Wang K, Evans SE, Chen F (2007) High temporal but low spatial heterogeneity of bacterioplankton in the Chesapeake Bay. Appl Environ Microbiol 73: 6776-6789
Karner M, Fuhrman JA (1997) Determination of active marine bacterioplankton: a comparison of universal 16S rRNA probes, autoradiography, and nucleoid staining. Appl Environ Microbiol 63:1208-1213

- Kirchman DL (1994) The uptake of inorganic nutrients by heterotrophic bacteria. Microb Ecol 28:255-271

> Kirchman DL, Dittel AI, Malmstrom RR, Cottrell MT (2005) Biogeography of major bacterial groups in the Delaware Estuary. Limnol Oceanogr 50:1697-1706

> Koizumi Y, Kojima H, Fukui M (2003) Characterization of depth-related microbial community structure in lake sediment by denaturing gradient gel electrophoresis of amplified 16S rDNA and reversely transcribed 16S rRNA fragments. FEMS Microbiol Ecol 46:147-157

Kruskal JB (1964) Nonmetric multidimensional scaling: a numerical method. Psychometrika 29:115-129

> Lancelot C, Billen G (1984) Activity of heterotrophic bacteria and its coupling to primary production during the spring phytoplankton bloom in the Southern Bight of the North Sea. Limnol Oceanogr 29:721-730

Luria C (2010) Factors influencing the abundance, community composition and activity state of bacterioplankton from the tidal freshwater James River. MSc thesis, Virginia Commonwealth University, Richmond, VA

> Manefield M, Whiteley AS, Griffiths RI, Bailey MJ (2002) RNA stable isotope probing, a novel means of linking microbial community function to phylogeny. Appl Environ Microbiol 68:5367-5373

- Marshall HG, Lane MF, Nesius KK, Burchardt L (2009) Assessment and significance of phytoplankton species composition within Chesapeake Bay and Virginia tributaries through a long-term monitoring program. Environ Monit Assess 150:143-155

Mather PM (1976) Computational methods of multivariate analysis in physical geography. J Wiley \& Sons, London

McCarren J, Becker JW, Repeta DJ, Shi Y and others (2010) Microbial community transcriptomes reveal microbes and metabolic pathways associated with dissolved organic matter turnover in the sea. Proc Natl Acad Sci USA 107:16420-16427

> McManus GB, Griffin PM, Pennock JR (2004) Bacterioplankton abundance and growth in a river-dominated estuary: relationships with temperature and resources. Aquat Microb Ecol 37:23-32

> Mou X, Sun S, Edwards RA, Hodson RE, Moran MA (2008) Bacterial carbon processing by generalist species in the coastal ocean. Nature 451:708-711

Östman O, Drakare S, Kritzberg ES, Langenheder S, Logue JB, Lindström ES (2010) Regional invariance among microbial communities. Ecol Lett 13:118-127

> Pennanen T, Caul S, Daniell TJ, Griffiths BS, Ritz K, Wheatley RE (2004) Community-level responses of metabolically-active soil microorganisms to the quantity and quality of substrate inputs. Soil Biol Biochem 36:841-848

> Polz MF, Cavanaugh CM (1998) Bias in template-to-product ratios in multitemplate PCR. Appl Environ Microbiol 64: 3724-3730

> Rodríguez-Blanco A, Ghiglione J, Catala P, Casamayor EO, Lebaron P (2009) Spatial comparison of total vs. active bacterial populations by coupling genetic fingerprinting and clone library analyses in the NW Mediterranean Sea. FEMS Microbiol Ecol 67:30-42

> Rosset R, Julien J, Monier R (1966) Ribonucleic acid composition of bacteria as a function of growth rate. J Mol Biol $18: 308-320$ 
Ruiz-González C, Lefort T, Galí T, Montserrat Sala M, Sommaruga R, Simó R, Gasol JM (2012) Seasonal patterns in the sunlight sensitivity of bacterioplankton from Mediterranean surface coastal waters. FEMS Microbiol Ecol 79:661-674

Servais P, Agogue H, Courties C, Joux F, Lebaron P (2001) Are the actively respiring cells (CTC+) those responsible for bacterial production in aquatic environments? FEMS Microbiol Ecol 35:171-179

Shen J, Lin J (2006) Modeling study of the influences of tide and stratification on age of water in the tidal James River. Estuar Coast Shelf Sci 68:101-112

Shen J, Boon JD, Kuo AY (1999) A modeling study of a tidal intrusion front and its impact on larval dispersion in the James River estuary, Virginia. Estuaries 22:681-692

Sherr E, Sherr B (1988) Role of microbes in pelagic food webs: a revised concept. Limnol Oceanogr 33:1225-1227

Sherr EB, Sherr BF, Sigmon CT (1999) Activity of marine bacteria under incubated and in situ conditions. Aquat Microb Ecol 20:213-223

Shiah FK, Ducklow HW (1994) Temperature regulation of heterotrophic bacterioplankton abundance, production, and specific growth rate in Chesapeake Bay. Limnol Oceanogr 39:1243-1258

Shiah FK, Ducklow HW (1995) Regulation of bacterial abundance and production by substrate supply and bacterivory: a mesocosm study. Microb Ecol 30:239-255

Sjöstedt J, Koch-Schmidt P, Pontarp M, Canbäck B and others (2012) Recruitment of members from the rare biosphere of marine bacterioplankton communities after an environmental disturbance. Appl Environ Microbiol 78: 1361-1369

Sloan WT, Lunn M, Woodcock S, Head IM, Nee S, Curtis TP (2006) Quantifying the roles of immigration and chance in shaping prokaryote community structure. Environ

Editorial responsibility: Paul del Giorgio, Montreal, Quebec, Canada
Microbiol 8:732-740

Smith EM (1998) Coherence of microbial respiration rate and cell-specific bacterial activity in a coastal planktonic community. Aquat Microb Ecol 16:27-35

> Smith EM, del Giorgio PA (2003) Low fractions of active bacteria in natural aquatic communities? Aquat Microb Ecol 31:203-208

Stepanauskas R, Edling H, Tranvik LJ (1999) Differential dissolved organic nitrogen availability and bacterial aminopeptidase activity in limnic and marine waters. Microb Ecol 38:264-272

> Thingstad TF, Lignell R (1997) Theoretical models for the control of bacterial growth rate, abundance, diversity and carbon demand. Aquat Microb Ecol 13:19-27

> Troussellier M, Schäfer H, Batailler N, Bernard L and others (2002) Bacterial activity and genetic richness along an estuarine gradient (Rhone River plume, France). Aquat Microb Ecol 28:13-24

Ullrich S, Karrasch B, Hoppe HG, Jeskulke K, Mehrens M (1996) Toxic effects on bacterial metabolism of the redox dye 5-cyano-2,3-ditolyl tetrazolium chloride. Appl Environ Microbiol 62:4587-4593

> Wagner R (1994) The regulation of ribosomal-RNA synthesis and bacterial cell growth. Arch Microbiol 161:100-109

> Wang Q, Garrity GM, Tiedje JM, Cole JR (2007) Naive Bayesian classifier for rapid assignment of rRNA sequences into the new bacterial taxonomy. Appl Environ Microbiol 73:5261-5267

White PA, Kalff J, Rasmussen JB, Gasol JM (1991) The effect of temperature and algal biomass on bacterial production and specific growth rate in fresh-water and marine habitats. Microb Ecol 21:99-118

> Woodcock S, van der Gast CJ, Bell T, Lunn M, Curtis TP, Head IM, Sloan WT (2007) Neutral assembly of bacterial communities. FEMS Microbiol Ecol 62:171-180

Submitted: December 17, 2012; Accepted: April 11, 2013 Proofs received from author(s): July 1, 2013 